Owner: Riset \& Jurnal Akuntansi

e-ISSN : 2548-9224 | p-ISSN : 2548-7507

Volume 6 Nomor 1, Januari 2022

DOI : https://doi.org/10.33395/owner.v6i1.676

\title{
Pengaruh Struktur Modal, Pertumbuhan laba terhadap kualitas laba dan ukuran perusahaan sebagai variabel moderasi
}

\author{
Jaenal Abidin ${ }^{\text {* }}$, Lodang Prananta Widya Sasana ${ }^{2 *}$, Amelia $^{3^{*}}$ \\ Universitas Pamulang, Indonesia \\ JaenalAbidin328@gmail.com, dosen02227@unpam.ac.id, Ameliabimay04@gmail.com
}

*Corresponding Author

Diajukan : 10 Januari 2022

Disetujui : 18 Januari 2022

Dipublikasi : 24 Januari 2022

\section{ABSTRACT}

Earnings quality as a measuring tool to assess the quality of financial information. The high quality of financial information comes from the high quality of financial reports. The purpose of this study is to examine the effect of capital structure, earning growth on earnings quality and firm size as moderasi variabels. The independen variabels used in this study are capital structure and earning growth. While the dependent variabel in this study is earning quality, and the moderasi variabel in this study is firm size. The type of research used in this study is quantitative research. Sources of data used in this study is secondary data. The populations in this study is the banking subsector companies listed on the Indonesia stock exchange during the 2015-2019 period. Determination of the sample in this study using purposive sampling method and obtained as many as 10 campanies multiplied by a period of 5 year so that the sample in this study is 50. The analysis using E-Views version 9 software. The results of this study indicate that the capital structure partially has no effect on earning quality. Profit growth partially has a negative effect on earning quality. Firm size partially effects has a positive effect on earning quality. Firm size partially doesn't moderate capital structure on earning quality. Firm size partially doesn't moderate earning growth on earning quality. Capital structure, earning growth, firm size simultaneously effect earning quality.

Keywords : Capital Structure, Earning Growth, Firm Size, Earning Quality.

\section{PENDAHULUAN}

Akuntansi menghasilkan informasi keuangan pada bank, Informasi keuangan yang dihasilkan oleh proses akuntansi disebut laporan keuangan. Laporan keuangan pada bank dapat diperoleh informasi tentang posisi keuangan bank, kinerja bank, aliran kas bank, dan informasi yang berkaitan dengan laporan keuangan termasuk mengenai laba yang diperoleh bank tersebut. Gahani Purnama Wati dan I Wayan Putra (2017) menyatakan kualitas laba sebagai salah satu alat ukur untuk menilai kualitas informasi keuangan. Pentingnya informasi laba juga dijelaskan dalam Statement Of Financial Accounting (SFAC) No.1 yang menyatakan bahwa laba selain digunakan untuk menilai kinerja manajemen juga dapat membantu mengestimasi 
Owner: Riset \& Jurnal Akuntansi

e-ISSN : 2548-9224 | p-ISSN : 2548-7507

Volume 6 Nomor 1, Januari 2022

DOI : https://doi.org/10.33395/owner.v6i1.676

RISET \& JURNAL AKUNTANSI

kemampuan laba yang representatif, serta untuk menaksir risiko dalam suatu investasi atau kredit.

Struktur modal merupakan perbandingan antara modal asing dan modal sendiri. Menurut Angga Dwi Pratama dan Sunarto (2018) struktur modal merupakan alat untuk mengukur seberapa jauh suatu perusahaan bergantung pada kreditor dalam membiayai aset perusahaan. Struktur modal dapat mempengaruhi kualitas laba karena apabila leverage suatu perusahaan tinggi, maka berarti kegiatann operasional perusahaan tersebut lebih banyak dibiayai oleh hutang.

Pertumbuhan laba berarti kinerja perusahaan berjalan dengan baik dan dimungkinkan memiliki pertumbuhan kualitas labanya (Alfiati Silfi, 2016). Jika suatu perusahaan memiliki kesempatan untuk meningkatkan labanya perusahaan mencerminkan laporan keuangan yang dapat dipercaya. Menurut Adella dan Cahyaningsih (2020) jika perusahaan memiliki kesempatan bertumbuh terhadap labanya berarti perusahaan tersebut baik dan memungkinkan juga memiliki kesempatan bertumbuh atas kualitas labanya.

Linda Anggraini dan Maswar Patuh Priyadi (2019) menyatakan ukuran perusahaan adalah suatu ukuran yang dapat diklasifikasikan besar kecilnya perusahaan menggunakan $l o g$ size. Haris Prasetya dalam Bagus Rahmat Setiawan (2017) menyatakan ukuran perusahaan adalah suatu skala dimana perusahaan diklasifikasikan menurut besar kecilnya bedasarkan pada total aset suatu perusahaan, semakin besar total aset maka semakin besar pula ukuran perusahaan tersebut. Bagus Rahmat Setiawan (2017) menyebutkan investor biasanya lebih memiliki kepercayaan kepada perusahaan besar, karena perusahaan besar dianggap mampu untuk terus meningkatkan kinerja perusahaanya dengan berupaya meningkatkan labanya.

Berdasarkan sumber kompas.com, kasus yang terjadi di indonesia terhadap praktik manajemen laba yaitu pernah terjadi pada PT. BANK Bukopin Tbk (BBKP) yang mencatat laba tahun 2016 sebesar Rp. 1,08 triliun. Namun, dalam laporan keuangan perusahaan tahun 2017, laba perusahaan dicatatkan sebesar 183,53 Miliar. Manajemen bukopin mengungkapkan bahwa perubahan tersebut dipicu adanya pencatatan tak wajar alias abnormal dari sisi pendapatan bisnis kartu kredit. Bank bukopin merevisi turun laba bersih 2016 menjadi Rp. 183,56 Miliar dari sebelumnya Rp. 1,08 triliun. Penurunan terbesar adalah di bagian pendapatan provisi dan komisi yang merupakan pendapatan dari kartu kredit. Pendapatan ini turun dari Rp 1,06 triliun menjadi Rp. 317,88 miliar.

Selain masalah kartu kredit, revisi juga terjadi pada pembiayaan anak usaha Bank Syariah Bukopin (BSB) terkait penambahan saldo cadangan kerugian penurunanan nilai debitur tertentu. Akibatnya, beban penyisihan kerugian penurunan nilai atas aset keuangan direvisi meningkat dari Rp. 649,05 miliar menjadi Rp. 797,65 miliar. Hal ini menyebabkan beban perseroan meningkat Rp.148,6 miliar. Sebelum otoritas melakukan klarifikasi, Bukopin telah "dihukum" atas insiden ini. Bukopin telah merevisi turun ekuitas yang dimiliki sebesar Rp. 2,62 triliun pada akhir 2016, dari Rp. 9,53 triliun menjadi Rp. 6,91 triliun. Penurutnan itu karena revisi turun saldo laba Rp. 2,62 triliun menjadi Rp. 5,52 triliun karena laba yang dilaporkan sebelumnya tidak benar. 
Owner: Riset \& Jurnal Akuntansi

e-ISSN : 2548-9224 | p-ISSN :2548-7507

Volume 6 Nomor 1, Januari 2022

DOI : https://doi.org/10.33395/owner.v6i1.676

Penjabaran kasus diatas, peneliti menyimpulkan bahwa PT. Bank Bukopin telah melanggar etika dalam akuntansi keuangan, yaitu mencatat laporan keuangan secara tidak profesional menyebabkan revisi laporan sebanyak 3x. Tetapi PT. Bank Bukopin cukup obyektif, karena manajemen memberi tahu adanya kejanggalan dalam laporan keuangannya. Melihat ketidakcocokan data tersebut, pihak PT. Bank Bukopin langsung melaporkan kepada kantor akuntan publik (KAP) dan juga otoritas jasa keuangan (OJK), dan PT. Bank Bukupin terang-terangan merevisi laporan keuangannya.

Penyimpangan etika dalam akuntansi keuangan PT. Bank Bukopin yaitu adanya fraud accouting yaitu suatu tindak kesengajaan menggunakan sumber daya perusahaan secara tidak wajar dan salah menyajikan fakta untuk memperoleh keuntungan pribadi. Selain itu, penyimpangan etika lain yaitu terjadi whistle blowing internal yang artinya penyimpangan atau kecurangan karyawan yang dilaporan oleh pihak internal, yaitu pimpinan perusahaan tertinggi.

\section{STUDI LITERATUR}

\section{Teori Pengaruh Struktur Modal terhadap Kualitas Laba}

Alfiati Silfi (2016) menyebutkan struktur modal yang diukur dengan leverage merupakan suatu variabel yang untuk mengetahui seberapa besar aset perusahaan dibiayai oleh utang perusahaan.. Apabila perusahaan mempunyai tingkat leverage berarti semakin tinggi resiko karena ada kemungkinan perusahaan tidak dapat melunasi kewajibannya baik berupa pokok maupun bunganya (Angga Dwi Pratama dan Sunarto, 2018). Jika suatu tingkat leverage suatu perusahaan tinggi maka akan memilik kecenderungan untuk melakukan praktik laba yang besar sehingga kualitas laba yang dihasilkan menjadi rendah (Gosh dan Moon dalam Bagus Rahmat Setiawan (2017). Menurut zein dalam Nadila Al-Vionita dan Nur Fadjrih Asyik (2020) menyebutkan bahwa tingginya tingkat leverage menyebabkan investor takut berinvestasi diperusahaan tersebut, karena investor tidak ingin mengambil risiko yang besar.

\section{$H_{1}$ : Struktur modal berpengaruh secara parsial terhadap kualitas laba pada Perbankan yang terdaftar Di BEI}

\section{Teori Pengaruh Pertumbuhan Laba terhadap Kualitas Laba}

Laba merupakan salah satu indikator penting untuk menilai kinerja usaha tersebut selama periode tertentu. Setiap perusahaan pasti menginginkan adanya peningkatan laba yang diperoleh dalam setiap tahunnya. Nadila Al-Vionita dan Nur Fadjrih Asyik (2020) menyatakan Pertumbuhan laba adalah suatu perubahan laba yang meningkat atau menurun yang dinyatakan dalam persentase. Dengan adanya pertumbuhan laba berarti kinerja perusahaan berjalan dengan baik dan dimungkinkan memiliki pertumbuhan kualitas labanya (Alfiati Silfi, 2016). Nadila Al-Vionita dan Nur Fadjrih Asyik (2020) menyebutkan pertumbuhan laba digunakan sebagai penentu kenaikan atau penurunan laba yang dialami perusahaan.

\section{$\mathrm{H}_{2}$ : Struktur pertumbuhan laba secara parsial terhadap kualitas laba pada Perbankan yang terdaftar Di BEI}

\section{Teori Pengaruh Ukuran Perusahaan terhadap Kualitas Laba}


Owner: Riset \& Jurnal Akuntansi

e-ISSN : 2548-9224 | p-ISSN : 2548-7507

Volume 6 Nomor 1, Januari 2022

DOI : https://doi.org/10.33395/owner.v6i1.676

RISET \& JURNAL AKUNTANSI

Gahani Purnama Wati dan I Wayan Putra (2017) menyatakan ukuran perusahaan pada dasarnya merupakan pengelompokan perusahaan ke dalam beberapa kelompok, diantaranya adalah perusahaan dengan ukuran besar, sedang, dan kecil. Perusahaan yang besar mempunyai berbagai kelebihan dibanding perusahaan berukuran kecil. Bagus Rahmat Setiawan (2017) menyebutkan ukuran perusahaan adalah suatu skala dimana perusahaan diklasifikasikan menurut besar kecilnya berdasarkan pada total aset suatu perusahaan, semakin besar total aset maka semakin besar pula ukuran perusahaan tersebut. Hal ini disebabkan perusahaan besar di asumsikan memiliki kesempatan yang besar dalam memenangkan persaingan antar perusahaan (Linda Anggrainy dan Maswar Patuh Priyadi, 2019). Perusahaan yang berskala besar akan lebih mudah mendapatkan pinjaman dari pihak ketiga karena memiliki jaminan aktiva yang lebih besar daripada perusahaan yang berskala kecil (Angga Dwi Pratama dan Sunarto, 2108).

\section{$\mathrm{H}_{3}$ : Ukuran perusahaan secara parsial terhadap kualitas laba pada Perbankan yang terdaftar Di BEI}

\section{Teori Modearasi Ukuran Perusahaan atas pengaruh Struktur terhadap Kualitas Laba}

Struktur modal yang menentukan apakah perusahaan menggunakan dana internal atau dana eksternal dalam memenuhi pendanaan perusahaan. Ukuran perusahaan menjadi salah satu hal yang penting dilihat bagi para investor, semakin besar ukuran perusahaan, investor semakin percaya dan yakin untuk melakukan investasi diperusahaan tersebut dan berharap perusahaan terus dapat menjalankan operasionalnya dengan baik sehingga deviden yang didapatkan akan semakin besar. Perusahaan berupaya meningkatkan kinerjanya sehingga mendapatkan laba sebanyak-banyaknya. Sesuai dengan penelitian yang telah di lakukan oleh Maulina Supomo dan Lailatur Amanah (2019) menyatakan struktur modal berpengaruh signifikan terhadap kualitas laba. Dari hasil penelitian tersebut, peneliti menarik kesimpulan bahwa ukuran perusahaan yang besar maka perusahaan mendapatkan tingkat struktur modal yang tinggi, apabila tingkat struktur modal tinggi maka akan memberikan pengaruh terhadap kualitas labanya.

\section{$\mathrm{H}_{4}$ : Ukuran perusahaan memperkuat pengaruh struktur modal terhadap kualitas laba pada Perbankan yang terdaftar Di BEI}

\section{Teori Modearasi Ukuran Perusahaan atas pengaruh Pertumbuhan Laba terhadap Kualitas Laba}

Perusahaan yang besar pada umumnya memiliki nilai pertumbuhan laba, pertumbuhan laba terjadi karena adanya perubahan tingkat laba yang didapatkan perusahaan dalam suatu periode. Jika perusahaan semakin besar maka kegiatann operasional perusahaan akan semakin besar dan kinerja perusahaan dinilai baik, dan laba yang akan dihasilkan akan berubah setiap periodenya. Ukuran perusahaan merupakan besarnya asset yang dimiliki perusahaan. Perusahaan besar cenderung bertindak hati-hati dalam melakukan pengelolaan perusahaan dan cenderung melakukan pengelolaan laba secara efisien. Perusahaan yang besar lebih diperhatikan oleh masyarakat sehingga mereka akan lebih berhati-hati dalam melakukan pelaporan keuangan (Darabali dan Saitri, 2016). Ukuran perusahaan yang besar serta adanya pertumbuhan laba yang dihasilkan dalam setiap periode cenderung melakukan pengelolaan 
Owner: Riset \& Jurnal Akuntansi

e-ISSN : 2548-9224 | p-ISSN :2548-7507

Volume 6 Nomor 1, Januari 2022

DOI : https://doi.org/10.33395/owner.v6i1.676

laba secara efesien. Perusahaan yang besar lebih diperhatikan oleh masyarakat dan investor sehingga mereka akan lebih berhati-hati dalam melakukan pelaporan keuangan.

\section{H5 : Ukuran perusahaan memperkuat pengaruh pertumbuhan laba terhadap kualitas laba pada Perbankan yang terdaftar Di BEI}

\section{Teori Pengaruh Struktur Modal, Pertumbuhan Laba, Ukuran Perusahaan terhadap Kualitas Laba}

Siti Alfiati (2016) menyebutkan Leverage suatu perusahaan untuk mengetahui seberapa besar aset perusahaan yang dibiayai oleh hutang perusahaan.Tingginya tingkat leverage biasanya manajemen cenderung untuk melakukan praktik laba yang besar sehingga kualitas laba yang dihasilkan menjadi rendah Gahani Purnamawati dan I Wayan Putra (2017). Linda Anggrainy dan Maswar Patuh Priyadi (2019) menyebutkan pertumbuhan laba adalah suatu perubahan laba yang meningkat atau menurun yang dinyatakan dalam persentase. Gahani Purnama wati dan I Wayan Putra (2017) menyebutkan perusahaan yang besar dan luas juga lebih mudah memperoleh sumber pendanaan dari luar dan juga mampu bertahan dan bersaing dalam industri.

\section{H6 : Secara simultan antara struktur modal, pertumbuhan laba, ukuran perusahaan terhadap kualitas laba}

\section{Pendekatan Penelitian}

\section{METODE}

Dalam penelitian ini menggunakan metode kuantitatif dan data yang digunakan data sekunder. Sugiyono (2017:8) penelitian kuantitatif adalah metode penelitian yang berlandaskan pada filsafat positivisme, digunakan untuk meneliti pada populasi atau sampel tertentu, pengumpulan data menggunakan instrument penelitian, analisis data bersifat kuantitatif, dengan tujuan untuk menguji hipotesis yang telah ditetapkan. Sugiyono (2017:137) menjelaskan data sekunder adalah sumber data yang tidak langsung memberikan data kepada pengumpul data yang bersumber dari buku-buku, literatur dan bacaan yang berkaitan dan menunjang penelitian ini.

\section{Jenis Penelitian}

Sedangkan metode asosiatif menurut Sugiyono (2019:23) dalam penelitian kuantitatif, karena peneliti tidak berinteraksi dengan sumber data, maka akan terbebas dari nilai - nilai yang dibawa peneliti dan sumber data. Karena ingin bebas nilai, maka peneliti menjaga jarak dengan sumber data, supaya data yang diperoleh obyektif.

\section{Populasi dan Sample}

Sugiyono (2017:80) populasi adalah wilayah generalisasi yang terdiri atas objek atau subjek yang mempunyai kuantitas dan karateristik tertentu yang ditetapkan oleh peneliti untuk dipelajari dan kemudian ditarik kesimpulan. Populasi yang digunakan dalam penelitian ini adalah seluruh perusahaan yang sudah terdaftar di BEI dalam sub sektor perbankan, yang berjumlah 43 Bank. 
Owner: Riset \& Jurnal Akuntansi

e-ISSN : 2548-9224 | p-ISSN :2548-7507

Volume 6 Nomor 1, Januari 2022

DOI : https://doi.org/10.33395/owner.v6i1.676

Sugiyono (2017:81) sampel adalah bagian dari jumlah dan karateristik yang dimiliki oleh populasi tersebut. Bila populasi besar, dan peneliti tidak mungkin mempelajari semua yang ada pada populasi, misalnya karena keterbatasan dana, tenaga, dan waktu, maka peneliti dapat menggunakan sampel yang diambil dari populasi itu. Teknik sampel yang diambil menggunakan teknik purposive sampling. Prof. Dr. Sugiyono (2017:85) purposive sampling adalah teknik untuk menentukan sampel penelitian dengan beberapa pertimbangan tertentu yang bertujuan agar data yang diperoleh nantinya bisa lebih representatif. Sampel penelitian yang dipilih dengan kriteria yaitu 10 urutan bank umum terbaik yang terdaftar di Bursa Efek Indonesia (BEI).

1. Bank umum yang telah terdaftar di bursa Efek Indonesia (BEI) selama periode 20152019 dalam sub sektor perbankan.

2. Bank yang menerbitkan laporan keuangan tahunan selama periode tahun 2015-2019 di bursa Efek Indonesia (BEI) secara berturut-turut.

3. Melaporkan laporan keuangan dalam periode 31 Desember tiap tahunnya menggunakan satuan rupiah selama periode tahun 2015-2019.

4. 10 urutan bank umum yang terbaik yang terdaftar di bursa Efek Indonesia (BEI)

Tabel 1. Daftar Sampel Bank Umum di Indonesia

\begin{tabular}{|c|l|}
\hline No & \multicolumn{1}{|c|}{ Nama Bank } \\
\hline 1 & PT. Bank Rakyat Indonesia (PERSERO) Tbk \\
\hline 2 & PT. Bank Mandiri (PERSERO) Tbk \\
\hline 3 & PT. Bank Central Asia Tbk \\
\hline 4 & PT. Bank Negara Indonesia (PERSERO) Tbk \\
\hline 5 & PT. Bank Tabungan Negara (PERSERO) Tbk \\
\hline 6 & PT. Bank Cimb Niaga Tbk \\
\hline 7 & PT. Pan Indonesia Bank Tbk \\
\hline 8 & PT. Bank OCBC NISP Tbk \\
\hline 9 & PT. Bank Danamon Indonesia Tbk \\
\hline
\end{tabular}

Sumber: Data diolah oleh penulis.

\section{Analisis Regresi Data Panel}

Analisis regresi data panel adalah data time series dan cross section. Dalam regresi data panel dikenal dengan tiga macam pendekatan yang terdiri dari pendekatan kuadrat kecil (common effect model) menurut Bagus Rahmat Setiawam (2017) menyatakan model estimasi yang menggabungkan data time series dan data cross section dengan menggunakan pendekatan OLS (Ordinary Least Square) untuk mengestimasi parameternya., pendekatan efek tetap (fixed effect), dan pendekatan efek random (random effect) Pendekatan model random effect ini adalah mengatasi kelemahan dari model fixed effect. Model ini dikenal juga dengan sebutan model generalized least square (GLS). Apabila probabilitas signifikan F statistik $<\alpha=0,05$ maka model yang lebih baik adalah model fixed effect, namun jika nilai probabilitas signifikan F statistik $>\alpha=0,05$ maka model yang lebih baik adalah model common effect.

\section{Pengujian Model}

Dalam penelitian ini, model penelitian menggunakan Uji chow, Uji hausman dan Uji Lagrange Multiplier. Uji chow digunakan untuk menguji test for quality of coefficients atau uji kesamaan koefisien. Uji ini digunakan untuk pemilihan antara model fixed effect dan common 
Owner: Riset \& Jurnal Akuntansi

e-ISSN : 2548-9224 | p-ISSN : 2548-7507

Volume 6 Nomor 1, Januari 2022

DOI : https://doi.org/10.33395/owner.v6i1.676

RISET \& JURNAL AKUNTANSI

effect. Chow test adalah uji dengan melihat dari hasil F statistik memilih model yang baik antara model common effect ataupun fixed effect. Uji hausman digunakan untuk memilih apakah model fixed effect atau random effect yang paling tepat digunakan.

\section{Uji Asumsi Klasik}

Uji normalitas bertujuan untuk menguji apakah nilai residual yang telah terstandarisasi pada model regresi berdistribusi normal atau tidak. Uji multikolonieritas digunakan untuk mengetahui apakah model regresi memiliki korelasi antara variabel bebas. Menurut Ghozali (2018:139) uji heterokedastisitas bertujuan untuk menguji apakah dalam model regresi terjadi ketidaksamaan variance dari residual satu pengamatan ke pengamatan yang lain. Uji autokorelasi bertujuan menguji apakah dalam model regresi linier ada korelasi antara kesalahan pengganggu pada periode $\mathrm{t}$ dengan kesalahan penggunaan pada periode $\mathrm{t}-1$ (sebelumnya).

\section{Model Analisis Peneltian}

Dalam penelitian ini, metode yangi digunakan yaitu metode analisis statistik. Sebelum data akan dianalisis, terlebih dahulu dilakukan uji t asumsi klasik sebelum melakukan pengujian hipotesis. Model analisis data menggunakan analisis regresi berganda untuk mengetahui pengaruh variable bebas (independen) dan variable terikat/dependen digunakan rumus analisis regresi linier berganda sebagai berikut:

\section{Uji Signifikan Secara Simultan (Uji-F)}

$$
Y=\alpha+\beta_{1} X_{1}+\beta_{2} X_{2}+\beta_{3} Z+e
$$

Menurut Sunyoto (Purba et al., 2020), "Uji F dilakukan untuk mengetahui pengaruh antaravariabel bebas terhadap variabel terikat secara bersama-sama/simultan."Pengujian dilakukan menggunakan tingkat signifikan 0,05 . Penerimaan atau penolakan hipotesis berdasarkan kriteria sebagai dan tingkat signifikan berikut:

1. Apabila $F_{\text {hitung }}<F_{\text {tabel }}$ maka semua variabel independen secara simultan tidak berpengaruh terhadap variabel dependen dan Apabila nilai signifikansi sama atau kurang dari 0,05 maka semua variabel independen secara bersama-sama signifikan terhadap variabel dependen.

2. Apabila $F_{\text {hitung }}>F_{\text {tabel }}$ maka semua variabel independen secara simultan berpengaruh terhadap variabel dependen dan Apabila nilai signifikansi lebih dari 0,05 maka semua variabel independen secara bersama-sama tidak signifikan terhadap variabel dependen.

\section{Uji Signifikan Secara Parsial (Uji-t)}

Menurut Sunyoto (Purba et al., 2020) "Uji t digunakan untuk mengetahui ada atau tidaknya hubungan atau pengaruh yang berarti atau signifikan antara variabel bebas secara parsial terhadap variabel terikat." Ketentuan dalam uji statistik T dan tingkat signifikan yaitu sebagai berikut:

1. Jika $T_{\text {hitung }}<T_{\text {tabel }}$ maka variabel independen secara parsial tidak berpengaruh terhadap variabel dependen dan Apabila nilai probabilitas lebih kecil dari tingkat signifikansi 
Owner: Riset \& Jurnal Akuntansi

e-ISSN : 2548-9224 | p-ISSN :2548-7507

Volume 6 Nomor 1, Januari 2022

DOI : https://doi.org/10.33395/owner.v6i1.676

$(\operatorname{sig}<0,05)$, maka variabel independen secara individual (parsial) signifikan terhadap variabel dependen.

2. Jika $T_{\text {hitung }}>T_{\text {tabel }}$ maka variabel independen secara parsial berpengaruh terhadap variabel dependen dan Apabila nilai probabilitas lebih besar dari tingkat signifikansi (sig>0,05), maka variabel independen secara individual (parsial) tidak signifikan terhadap variabel dependen.

\section{HASIL}

Tabel 2. Hasil Statistik Deskriptif

\begin{tabular}{|c|c|c|c|c|}
\hline \multicolumn{5}{|c|}{ Sample: 20152019} \\
\hline & Y & $\mathrm{X} 1$ & $\mathrm{X} 2$ & $\mathrm{Z}$ \\
\hline Mean & -17092.77 & 5.958017 & -0.409087 & 19.70284 \\
\hline Median & -16539.78 & 5.633695 & 0.111337 & 19.39079 \\
\hline Maximum & 34758.41 & 11.39583 & 3.865132 & 21.07164 \\
\hline Minimum & -47042.62 & 3.261265 & -27.23541 & 18.60700 \\
\hline Std. Dev. & 15093.90 & 1.917173 & 3.928401 & 0.790518 \\
\hline Skewness & 0.566501 & 1.483271 & -6.534354 & 0.401576 \\
\hline Kurtosis & 4.241010 & 4.914334 & 45.31563 & 1.535226 \\
\hline Jarque-Bera & 5.882915 & 25.96886 & 4086.258 & 5.813780 \\
\hline Probability & 0,052789 & 0.000002 & 0.000000 & 0,054645 \\
\hline Sum & -854638.4 & 297.9008 & -20.45436 & 985.1419 \\
\hline Sum Sq. Dev. & $1.12 \mathrm{E}+10$ & 180.1021 & 756.1845 & 30.62102 \\
\hline Observations & 50 & 50 & 50 & 50 \\
\hline
\end{tabular}

\section{Pengujian Model Panel}

Berdasarkan pengujian berpasangan terhadap ketiga model regresi data panel seperti yang ditunjukan dalam tabel 4 . hasil pengujian berpasangan menggunakan uji chow, uji hausman dan uji LM Breush-pagan (BP) dapat disimpulkan bahwa model fixed effect dalam metode regresi data panel digunakan lebih lanjut untuk mengestimasi penelitian pengaruh struktur modal, pertumbuhan laba terhadap kualitas laba dan ukuran perusahaan sebagai variabel moderasi.

Tabel 3. Kesimpulan Pengujian Model Regresi Data Panel

\begin{tabular}{|c|c|c|c|}
\hline No & Metode & Pengujian & Hasil \\
\hline 1 & Chow-Test & Common Effect vs Fixed Effect & Fixed Effect \\
\hline 2 & Hausman Test & Fixed Effect vs Random Effect & Fixed Effect \\
\hline
\end{tabular}


Owner: Riset \& Jurnal Akuntansi

e-ISSN : 2548-9224 | p-ISSN :2548-7507

Volume 6 Nomor 1, Januari 2022

DOI : https://doi.org/10.33395/owner.v6i1.676

\begin{tabular}{|l|l|l|c|}
3 & Lagrange Multiplier & Common Effect vs Random Effect & $\begin{array}{c}\text { Common } \\
\text { Effect }\end{array}$ \\
\hline
\end{tabular}

Sumber Tabel : Hasil Pengolahan Data (2021)

\section{Uji Normalitas}

Uji normalitas dipergunakan untuk melihat apakah nilai residual terdistribusi normal atau tidak. Dengan Jarque-Bera normalitas dari suatu data dapat ditunjukan dengan nilai probabilitas dari Jarque-Bera $>0,1$ dan sebaliknya data tidak berdistribusi normal bila probibalitas Jarque-Bera $<0,1$.

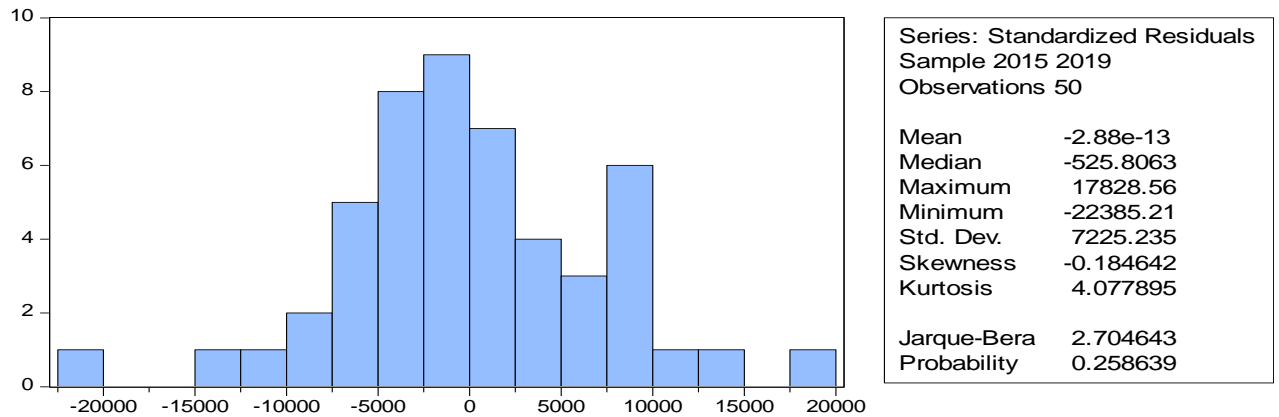

Gambar 1. Normalitas Grafik Histogram

Sumber: Hasil Pengolahan Data (2021)

Berdasarkan grafik histogram diatas diperoleh nilai Jarque-Bera sebesar 2,704643. Dengan Jarque-Bera normalitas dari suatu data dapat ditunjukan dengan nilai probabilitas dari Jarque-Bera $>0,1$ dan nilai probabilitas $0,258639>0,05(5 \%)$ yang berarti nilai residual berdistribusi normal.

\section{Uji Multikolinieritas}

Uji multikolonieritas digunakan untuk mengetahui apakah model regresi memiliki korelasi antara variabel bebas.

\begin{tabular}{|crrr|}
\hline & & & \\
& $\mathrm{X} 1$ & $\mathrm{X} 2$ & $\mathrm{Z}$ \\
\hline \hline $\mathrm{X} 1$ & 1.000000 & -0.140537 & -0.138322 \\
$\mathrm{X} 2$ & -0.140537 & 1.000000 & 0.137798 \\
$\mathrm{Z}$ & -0.138322 & 0.137798 & 1.000000 \\
\hline
\end{tabular}

Tabel 4. Hasil Uji Multikolinieritas

Sumber: Hasil Pengolahan Data (2021)

Dari tabel 4 diketahui bahwa tidak ada masalah multikolinieritas, hal ini dapat dilihat dari koefisien korelasi antar variabel $<0,90$ yang artinya tidak terdapat multikolinieritas antar variabel independen dalam model regresi. 
Owner: Riset \& Jurnal Akuntansi

e-ISSN : 2548-9224 | p-ISSN : 2548-7507

Volume 6 Nomor 1, Januari 2022

DOI : https://doi.org/10.33395/owner.v6i1.676

\section{Uji Heteroskedastisitas}

Uji heteroskedastisitas digunakan untuk mengetahui apakah dalam model regresi terjadi varian dari residual satu pengamatan ke pengamatan lainnya. Untuk mendeteksi ada atau tidaknya heteroskedastisitas menggunakan uji Breusch Pagan Godfrey (BPG) dengan nilai prob chi square (3) $>\alpha=0,05$. Berikut hasil uji heteroskedastisitas:

Tabel 5. Hasil Uji Heteroskedastisitas

\begin{tabular}{|llll|}
\hline \multicolumn{4}{l}{ Heteroskedasticity Test: Breusch-Pagan-Godfrey } \\
\hline \hline F-statistic & 0.593388 & Prob. F(3,46) & 0.6225 \\
Obs*R-squared & 1.862870 & Prob. Chi-Square(3) & 0.6014 \\
Scaled explained SS & 1.076734 & Prob. Chi-Square(3) & 0.7827 \\
\hline \hline
\end{tabular}

Sumber: Hasil Pengolahan Data (2021)

Dari tabel 4.8 diatas menunjukan bahwa nilai probabilitas chi square (3) adalah 0.6014 atau > dibandingkan 0,05, hal tersebut dapat disimpulkan bahwa uji Breusch Pagan Godfrey tidak mengidikasikan adanya gejala heterokedastisitas.

\section{Model Penelitian}

Tabel 6. Hasil Regresi Linier Berganda

\begin{tabular}{|crrrr|}
\hline \multicolumn{6}{|c|}{ Coefficient } & Std. Error & t-Statistic & Prob. \\
\hline \hline Variabel & Cry & \\
C & -407075.0 & 172588.1 & -2.358651 & 0.0237 \\
X1 & 3405.220 & 2071.140 & 1.644129 & 0.1086 \\
X2 & -1457.150 & 354.7261 & -4.107819 & 0.0002 \\
Z & 18733.23 & 8640.632 & 2.168039 & 0.0367 \\
\hline
\end{tabular}

Sumber: Hasil Pengolahan Data (2021)

Hasil yang telah diperoleh dari analisis regresi berganda diatas maka dibuat persamaan regresi sebagai berikut:

$\mathrm{Y}=\alpha+\beta 1 X 1+\beta 2 X 2+\beta 3 Z+\mathrm{e}$

$\mathrm{Y}=-407075.0+3405.220 \mathrm{X} 1-1457.150 \mathrm{X} 2+18733.23 \mathrm{Z}+\mathrm{e}$

Pengujian Hipotesis Secara Parsial (Uji t)

Tabel 7. Hasil Uji T

\begin{tabular}{|c|c|c|c|c|c|}
\hline & Variabel & Coefficient & Std. Error & t-Statistic & Prob. \\
\hline \multirow{3}{*}{ (c) (i) $(\mathrm{S}$} & C & -407075.0 & 172588.1 & -2.358651 & 0.0237 \\
\hline & $\mathrm{X} 1$ & 3405.220 & 2071.140 & 1.644129 & 0.1086 \\
\hline & A2 & $\begin{array}{r}-145 / .150 \\
18732\end{array}$ & $\begin{array}{l}354 . / 261 \\
8640.622\end{array}$ & $\begin{array}{r}-4.10 / 819 \\
2168039\end{array}$ & $\begin{array}{l}0.0002 \\
0.0367\end{array}$ \\
\hline
\end{tabular}


1. Struktur Modal $\mathrm{T}_{\text {hitung }}=1.644129$, sig $=0.1086, \mathrm{~T}_{\text {hitung }} 1.644129<\mathrm{T}_{\text {tabel }} 1.67866$. Hal ini menunjukan bahwa struktur modal secara parsial tidak berpengaruh signifikan terhadap kualitas laba. Dengan demikian $\mathrm{H}_{1}$ ditolak.

2. Pertumbuhan Laba $\mathrm{T}_{\text {hitung }}=-4.107819$, sig $=0.0002, \mathrm{~T}_{\text {hitung }}-4.107819<\mathrm{T}_{\text {tabel }} 1.67866$. Hal ini menunjukan bahwa pertumbuhan laba berpengaruh negatif dan signifikan secara parsial terhadap kualitas laba. Dengan demikian $\mathrm{H}_{2}$ diterima.

3. Ukuran Perusahaan $\mathrm{T}_{\text {hitung }}$ sebesar 2.168039, sig $=0.0367, \mathrm{~T}_{\text {hitung }} 2.168039>\mathrm{T}_{\text {tabel }} 1.67866$. Hal ini menunjukan bahwa ukuran perusahaan berpengaruh positif dan signifikan secara parsial terhadap kualitas laba. Dengan demikian $\mathrm{H}_{3}$ diterima.

\section{Pengujian Hipotesis Secara Simultan (Uji F)}

Tabel 8. Hasil Uji F

\begin{tabular}{lrlr}
\multicolumn{4}{l}{ Cross-section fixed (dummy variabels) } \\
\hline \hline R-squared & 0.770860 & Mean dependent var & -17092.77 \\
Adjusted R-squared & 0.696544 & S.D. dependent var & 15093.90 \\
S.E. of regression & 8314.750 & Akaike info criterion & 21.10834 \\
Sum squared resid & $2.56 \mathrm{E}+09$ & Schwarz criterion & 21.60547 \\
Log likelihood & -514.7086 & Hannan-Quinn criter. & 21.29765 \\
F-statistic & 10.37277 & Durbin-Watson stat & 2.700867 \\
Prob(F-statistic) & 0.000000 & & \\
\hline
\end{tabular}

Sumber: Output e-views 9, Data diolah

Berdasarkan tabel 8. menunjukan $F_{\text {hitung }}$ sebesar 10.37277 sementara $F_{\text {tabel }}$ dengan tingkat signifikansi 0,05 . Hal ini menunjukan bahwa struktur modal, pertumbuhan laba, dan ukuran peruashaan secara simultan berpengaruh positif dan signifikan terhadap kualitas laba. Dengan demikian $\mathrm{H}_{4}$ diterima.

\section{PEMBAHASAN}


Owner: Riset \& Jurnal Akuntansi

e-ISSN : 2548-9224 | p-ISSN : 2548-7507

Volume 6 Nomor 1, Januari 2022

DOI : https://doi.org/10.33395/owner.v6i1.676

\section{Pengaruh Struktur Modal terhadap Kualitas Laba}

Hasil penelitian ini adalah Struktur modal tidak berpengaruh terhadap kualitas laba pada Perbankan yang terdaftar Di BEI periode 2015-2019. Hasil penelitian ini sejalan dengan penelitian Angga Dwi Pratama dan Sunarto (2018) yang menyatakan struktur modal tidak berpengaruh terhadap kualitas laba.

\section{Pengaruh Pertumbuhan Laba terhadap Kualitas Laba}

Hasil penelitian ini adalah Pertumbuhan laba berpengaruh terhadap kualitas laba pada Perbankan yang terdaftar Di BEI periode 2015-2019. Hasil penelitian ini sejalan dengan penelitian Muhammad Faisa Arif (2020) yang menyatakan pertumbuhan laba berpengaruh terhadap kualitas laba.

\section{Pengaruh Ukuran Perusahaan terhadap Kualitas Laba}

Hasil penelitian ini adalah Ukuran perusahaan berpengaruh terhadap kualitas laba pada Perbankan yang terdaftar Di BEI periode 2015-2019. Hasil penelitian ini sejalan dengan Kadek Prawisanti Dira dan Ida Bagus Putra Astika (2014) yang menyatakan ukuran perusahaan berpengaruh terhadap kualitas laba.

\section{Moderasi Ukuran Perusahaan atas pengaruh Struktur Modal terhadap Kualitas Laba}

Hasil penelitian ini adalah Ukuran perusahaan tidak memoderasi struktur modal yang artinya ukuran perusahaan tidak memperkuat/memperlemah struktur modal terhadap kualitas laba. Hal ini dikarenakan ukuran perusahaan besar/kecil dengan struktur modal yang nilai tingkat leverage nya tinggi maka tetap akan menanggung risiko gagal bayar yang akan mengurangi nilai laba.

\section{Moderasi Ukuran Perusahaan atas pengaruh Pertumbuhan Laba terhadap Kualitas Laba}

Hasil penelitian ini adalah Ukuran perusahaan tidak memoderasi pertumbuhan laba yang artinya ukuran perusahaan tidak memperkuat/memperlemah pertumbuhan laba terhadap kualitas laba. Hal ini dikarenakan ukuran perusahaan besar/kecil tidak mempengaruhi pertumbuhan laba. Jika ukuran perusahaan yang besar tetapi tidak menjalankan kegiatann operasional nya dengan baik maka kinerja keuangan akan buruk dan laba yang dihasilkan tidak maksimal.

\section{KESIMPULAN}

Setelah peneliti melakukan pengolahan data dengan program software eviews (Econometric Views) 9 maka peneliti dalam penelitian ini menyimpulkan Struktur Modal (X1) tidak memiliki pengaruh terhadap kualitas laba (Y). Hal tersebut dapat dibuktikan pada hasil uji $\mathrm{T}$ diperoleh nilai struktur modal sebesar 0,1086 lebih besar dari taraf signifikan 0,05 yang menunjukan bahwa $\mathrm{H} 1$ ditolak. Hal ini berarti variabel struktur modal tidak berpengaruh signifikan terhadap kualitas laba.Pertumbuhan Laba (X2) memiliki pengaruh negatif terhadap kualitas laba (Y). Hal tersebut dapat dibuktikan pada hasil uji T diperoleh nilai pertumbuhan laba sebesar 0,0002 lebih kecil dari taraf signifikan 0,05 yang menunjukan bahwa $\mathrm{H} 2$ diterima. Hal ini berarti variabel pertumbuhan laba berpegaruh negatif dan signifikan terhadap kualitas 
Owner: Riset \& Jurnal Akuntansi

e-ISSN : 2548-9224 | p-ISSN : 2548-7507

Volume 6 Nomor 1, Januari 2022

DOI : https://doi.org/10.33395/owner.v6i1.676

laba.Ukuran Perusahaan (Z) memiliki pengaruh positif terhadap kualitas laba (Y). Hal tersebut dapat dibuktikan pada hasil uji $\mathrm{T}$ diperoleh nilai ukuran perusahaan sebesar 0,0367 lebih kecil dari taraf signifikan 0,05 yang menunjukan bahwa $\mathrm{H} 3$ diterima. Hal ini berarti variabel ukuran perusahaan berpengaruh positif dan signifikan terhadap kualitas laba.Ukuran Perusahaan (Z) tidak memoderasi pengaruh Struktur Modal (X1) terhadap Kualitas Laba (Y). Hal tersebut dapat dibuktikan pada hasil uji moderated regression analysis diperoleh nilai moderasi satu sebesar 0,7041 lebih besar dari taraf signifikan 0,05 yang menunjukan bahwa $\mathrm{H} 4$ ditolak. Hal ini berarti variabel ukuran perusahaan tidak memoderasi struktur modal terhadap kualitas laba. Ukuran Perusahaan (Z) tidak memoderasi Pertumbuhan Laba terhadap terhadap Kualitas Laba (Y) Hal tersebut dapat dibuktikan pada hasil uji moderated regression analysis diperoleh nilai moderasi satu sebesar 0,7442 lebih besar dari taraf signifikan 0,05 yang menunjukan bahwa H5 ditolak. Hal ini berarti variabel ukuran perusahaan tidak memoderasi pertumbuhan laba terhadap kualitas laba. Struktur Modal (X1), Pertumbuhan Laba (X2), Ukuran Perusahaan (Z) secara simultan memiliki pengaruh terhadap Kualitas Laba (Y). hal ini dapat dibuktikan pada uji $\mathrm{F}$ diperoleh nilai probabilitas sebesar 0,0000 lebih kecil dari taraf signifikan 0,05 yang menunjukan bahwa H6 diterima. Hal ini berarti struktur modal, pertumbuhan laba, dan ukuran perusahaan secara simultan atau bersamaan berpengaruh terhadap kualitas laba.

\section{REFERENSI}

Adella Diva Veratami, d. D. (2020). Pengaruh Pertumbuhan Laba, Kebijakan Deviden, dan Intensitas Modal Terhadap Kualitas Laba. e-Proceeding of Management , 7 (2), 31343142 .

Amanah, M. S. (2019). Pengaruh Komite Audit, Struktur Modal, dan Persistensi Laba terhadap Kualitas Laba. Jurnal Ilmu dan Riset Akuntansi : Volume 8, Nomor 5, e-ISSN: 2460$0585,1-17$.

Arif, M. F. (2020). PENGARUH PERTUMBUHAN LABA DAN INVESTMENT OPPORTUNITY SET TERHADAP KUALITAS LABA * JUMBO (Jurnal Manajemen, Bisnis dan Organisasi).

Astika, K. P. (2014). PENGARUH STRUKTUR MODAL, LIKUIDITAS, PERTUMBUHAN LABA, DAN UKURAN PERUSAHAAN PADA KUALITAS LABA. E-Jurnal Akuntansi Universitas Udayana 7.1 (2014):64-78 ISSN: 2302-8556 , 15.

Asyik, N. A.-V. (2020). Pengaruh Struktur Modal, Invesment Opportunity Set (IOS), dan Pertumbuhan Laba terhadap Kualitas Laba. Jurnal Ilmu dan Riset Akuntansi : Volume 9, Nomor 1, e-ISSN: 2460-0585, 1-18.

Banjarnahor, D. (2018, April 27). Drama Bank Bukopin : Kartu Kredit Modifikasi dan Right Issue. Dipetik November 20, 2020, dari CNBC Indonesia: https://www.cnbcindonesia.com

Darabali, P.M., \& P.W. Saitri. 2016. Analisis Faktor-Faktor yang Mempengaruhi Kualitas Laba Pada Perusahaan Manufaktur di Bursa Efek Indonesia Tahun 2010-2013. Jurnal Riset Akuntansi Juara 6(1): 46-60. 
Owner: Riset \& Jurnal Akuntansi

e-ISSN : 2548-9224 | p-ISSN :2548-7507

Volume 6 Nomor 1, Januari 2022

DOI : https://doi.org/10.33395/owner.v6i1.676

Destriana, S. S. (2015). Pengaruh Mekanisme Tata Kelola Perusahaan, Pendanaan Hutang Perusahaan, Dividen serta Ukuran Perusahaan terhadap Kualitas Laba. Jurnal Bisnis dan Akuntansi, Vol. 17, No. 2 ISSN 1410-9875

Ghozali. (2013). Aplikasi Analisis Multivariate dengan Program IBM SPSS Halaman 139 (7 ed.). Semarang: Universitas Diponegoro.

Ghozali. (2013). Aplikasi Analisis Multivariate dengan Program IBM SPSS Halaman 229 (7 ed.). Semarang: Universitas Diponegoro.

Ghozali. (2013). Aplikasi Analisis Multivariate dengan Program IBM SPSS Halaman 83 (7 ed.). Semarang: Universitas Diponegoro.

Ghozali. (2013). Aplikasi Analisis Multivariate dengan Program IBM SPSS Halaman 97 - 98 (7 ed.). Semarang: Universitas Diponegoro.

Nina Karina Karim, S. A. (2019, Oktober). Kulitas Laba dan Pengukurannya dalam Perusahaan Jasa Pendukung Industri Pariwisata. JMM Jurnal, 4(1).

Priyadi, L. A. (2019). Pengaruh Struktur Modal, Pertumbuhan Laba, Kualitas Audit, dan Ukuran Perusahaan terhadap Kualitas Laba. Jurnal Ilmu dan Riset Akuntansi : Volume 8, Nomor 6, e-ISSN: 2460-0585, 1-20.

Purba, A. R., Hutagalung, N. Y., Putri, E., \& Nazmi, H. (2020). PENGARUH KEPEMIMPINAN, MOTIVASI DAN KEDISIPLINAN TERHADAP KINERJA KARYAWAN PADA PT. SANTIKA PREMIERE DYANDRA. In Jurnal Ilmu Manajemen METHONOMIX (Vol. 3, Issue 1). www.methonomi.net

Putra, G. P. (2017). Pengaruh Ukuran Perusahaan, Leverage, dan Good Corporate Governance pada Kualitas Laba. E-Jurnal Akuntansi Universitas Udayana Vol.19.1. April (2017) ISSN: 2302-8556, 137-167.

Retnani, N. I. (2019). PENGARUH KINERJA KEUANGAN, PERTUMBUHAN LABA, DAN FREE CASH CLOW TERHADAP KUALITAS LABA. Jurnal Ilmu dan Riset Akuntansi e-ISSN: 2460-0585.

Setiawan, B. R. (2017). Pengaruh Ukuran Perusahaan, Profitabilitas, Likuiditas, dan Leverage terhadap Kualitas Laba pada Perusahaan Manufaktur Industri Barang Konsumsi yang Terdaftar di BEI. MENARA Ilmu Vol. XI Jilid 1 No.77 Oktober 2017 ISSN 1693-2617 , 36-46.

Shanie Sukmawati, K. d. (2014). Pengaruh Struktur Modal, Ukuran Perusahaan, Likuiditas, dan Return On Aset terhadap Kualitas Laba. Accounting Analysis Journal, 26-33.

Silfi, A. (2016). Pengaruh Pertumbuhan Laba, Struktur Modal, Likuiditas, dan Komite Audit terhadap Kualitas Laba. Jurnal Valuta Vol 2 No 1, April 2016, ISSN : 2502-1419 , 17 26. 
Owner: Riset \& Jurnal Akuntansi

e-ISSN : 2548-9224 | p-ISSN : 2548-7507

Volume 6 Nomor 1, Januari 2022

DOI : https://doi.org/10.33395/owner.v6i1.676

Sugiyono. (2016). Metode Penelitian Kuantitatif dan Kualitatif \& R\&D Halaman 39. Bandung: Alfabeta.

Sugiyono. (2017). Metode Penelitian Kuantitatif dan Kualitatif \& R\&D Halaman 137. Bandung: Alfabeta.

Sugiyono. (2017). Metode Penelitian Kuantitatif dan Kualitatif \& R\&D Halaman 59. Bandung: Alfabeta.

Sugiyono. (2017). Metode Penelitian Kuantitatif dan Kualitatif \& R\&D Halaman 60. Bandung: Alfabeta.

Sugiyono. (2017). Metode Penelitian Kuantitatif dan Kualitatif \& R\&D Halaman 8. Bandung: Alfabeta.

Sugiyono. (2017). Metode Penelitian Kuantitatif dan Kualitatif \& R\&D Halaman 80. Bandung: Alfabeta.

Sugiyono. (2017). Metode Penelitian Kuantitatif dan Kualitatif \& R\&D Halaman 81. Bandung: Alfabeta.

Sugiyono. (2017). Metode Penelitian Kuantitatif dan Kualitatif \& R\&D Halaman 85. Bandung: Alfabeta.

Sunarto, A. D. (2018). Struktur Modal, Komisaris Independen, Kepemilikan Manajerial, Kepemilikan Institusional dan Ukuran Perusahaan terhadap Kualitas Laba. Dinamika Akuntansi, Keuangan dan Perbankan, Vol. 7 No. 2, ISSN : 2656-4955 , 96-104.

The Statement of Financial Accounting (SFAC) No.1 